\title{
Medicinal plants with teratogenic potential: current considerations
}

\author{
Kassiane Cristine da Silva Costa ${ }^{1}$, Suzana Barbosa Bezerra ${ }^{1}$, Clevanice Moreira Norte $^{2}$, \\ Luciana Macatrão Nogueira Nunes ${ }^{3}$, Tiago Moreira de Olinda ${ }^{4, *}$
}

\author{
${ }^{1}$ Department of Pharmacy, Federal University of Ceará, ${ }^{2}$ Nursing, Federal University of Ceará, ${ }^{3}$ Federal University of \\ Rio de Janeiro, ${ }^{4}$ Department of Physiology and Pharmacology, Federal University of Ceará
}

\begin{abstract}
The aim of this study was to present the implications of the use of herbs during pregnancy, pointing out those that should be avoided during this condition because of their abortifacient and/or teratogenic potential. We carried out searches in the databases ScienceDirect, Scielo and Google Scholar, adopting as criteria for inclusion: book chapters and/or complete articles (with abstract), available in English, Portuguese or Spanish, published from 1996 to in 2011. After a pre-selection of 83 articles, 49 bibliographies were used in the manufacturing end of the article, where 25 were from the Scielo database, 18 from ScienceDirect and 6 from Google Scholar. From the articles studied, we identified the four most commonly used plants as emmenagogue/abortifacient agents by patients of the Department of Prenatal SUS: senne, arruda, boldo and buchinha-do-norte or cabacinha. Thus, we conclude that people often adhere to the maxim "if it's natural, it does no harm" in their rational use of natural products, without the right guidance, believing that these products are safe to use. This usage is even more worrisome among the elderly, pregnant women and children. Regarding the safety of these products, some information and reliable data are scarce or contradictory.
\end{abstract}

Uniterms: Medicinal plants/undue use/pregnancy. Medicinal plants/teratogenic activity. Medicinal plants/ emmenagogue/abortifacient agents. Natural products/adverse effects. Herbal medicines/adverse effects.

Este trabalho busca as implicações atuais sobre o uso de plantas medicinais durante a gravidez, alertando sobre aquelas que devem ser evitadas nesse período por serem potencialmente abortivas e/ou teratogênicas. Para tanto, foram realizadas buscas nas bases de dados Sciencedirect, Scielo e Google scholar, adotandose como critérios de inclusão capítulos de livros e/ou artigos completos (com abstract) e disponíveis, em português, inglês ou espanhol, publicados de 1996 a 2011. Após uma pré-seleção de 83 artigos, 49 bibliografias foram utilizadas na confecção final do artigo, sendo 25 provenientes da base de dados Scielo, 18 do Sciencedirect e 06 do Google scholar. A partir dos artigos estudados, identificaram-se as quatro plantas mais utilizadas como emenagogas/abortivas por pacientes do Serviço de Pré-Natal do SUS: senne, arruda, boldo e buchinha-do-norte ou cabacinha. Assim, é possível concluir que, muitas vezes, a população se utiliza da máxima "se é natural, não faz mal" para fazer uso irracional de produtos naturais, sem a correta orientação, acreditando que esses produtos sejam incapazes de provocar qualquer dano. Esse uso é ainda mais preocupante quando realizado por idosos, gestantes e crianças. Em relação à segurança do uso desses produtos, algumas informações e dados confiáveis ainda são escassos ou contraditórios.

Unitermos: Plantas medicinais/uso indevido/gravidez. Plantas medicinais/potencial teratogênico. Plantas medicinais/emenagogas/abortivas. Produtos naturais/efeitos adversos. Fitoterápicos/efeitos adversos.

\section{INTRODUCTION}

Since the dawn of human existence, cultures have used plants for the relief or cure of many different ailments

*Correspondence: T. M. Olinda. Departamento de Farmácia. Rua Cap. Francisco Pedro, 1210 - Rodolfo Teófilo - 60430-170 - Fortaleza - CE, Brazil. E-mail: tiago_olinda@yahoo.com.br
(Amorim et al., 2003). Historical records of 5000 years show that the Sumerians had used herbs for medicinal purposes, and the first book on herbs on record dates back to $2700 \mathrm{BCE}$ and comes from the Chinese with a list of 365 plants (Biazzi, 2003). There are also records of medicinal plants in Syria and Egypt (1500 b.C) and India (1500-1400 b.C), as well as evidence of their extensive use in North and South America by indigenous people (Fowler, 2006). 
In Brazil, records of the use of medicinal plants date from the time of its discovery, but it is known that the Native Americans who already lived here had knowledge of therapeutic plants from the national flora (Reis et al., 2004).

It is easy to understand the reason for the use of old plants for medicinal purposes. Only after the industrial revolution and the advancement of organic chemistry, did synthetic products gain supremacy in pharmacological treatments (Lamb et al., 2005), but before that, natural products were practically the only treatment option for diseases that afflicted humanity. According to estimates by the World Health Organization (WHO), $80 \%$ of the world's population uses the resources of popular medicines to meet the needs of primary health care, which can circulate about 22 billion dollars annually (Costa et al., 1998; Yunes et al., 2001).

In the United States alone, this market represents about US $\$ 5$ billion per year, the industry's fastest growing pharmaceutical market in the U.S. (Aschwanden, 2001). In Brazil, there are no official figures to date, but it is estimated that this market is around US\$ 160 million per year (Carvalho et al., 2008).

Despite such widespread and ancient use of natural products, only since 1978 has the World Health Organization officially recognized the use of herbal medicines for prophylactic, curative, palliative or diagnostic purposes, recommending the worldwide spread of the knowledge required for their use (Ministério da Saúde, 2001). The big problem is that these products are often used recklessly due to the belief that since they are natural, they are free of adverse reactions and toxic effects (Rates, 2001; Gallo, Koren, 2001).

In a survey conducted in Belo Horizonte (MG), 60\% of the population said they did not believe that plants and herbal medicines have toxic effects (Oliveira, Gonçalves, 2006). These results show that the idea of "natural, it does no harm" is a disturbing reality among users, and that effective measures are essential to focus on the rational use of medicinal plants and herbal medicines.

The lack of the minimum information necessary for the proper use of medicinal plants and herbal medicines makes them easy targets for self-medication without liability (Alexander et al., 2005). The ignorance of consumers often reflects the little knowledge of health professionals. In fact, studies show that many doctors, nurses and pharmacists are not adequately informed about the action, efficacy and safety of herbal medicines (Xu, Levine, 2008). Moreover, folklore and folk practices, rather than scientific studies, are often used as a means of obtaining information on indications, efficacy and safety of medicinal plants and herbal medicines (Alexander et al., 2005).
It should be noted that the medicinal plants used in herbal medicines contain xenobiotic agents, i.e., substances foreign to the human body, and as such, their biotransformation products can be potentially toxic. In addition to the immediate effects, which are readily correlated with their intake, effects that are established in the long-term may be asymptomatic, but can lead to a severe clinical picture, sometimes fatal (Lapa et al., 2004). It is possible to identify two types of adverse effects related to the use of medicinal plants. The first is considered intrinsic to these plants, where this toxicity may be related to an overdose and/or interaction with other drugs. The extrinsic one, however, is associated with the manufacture of the herbal product and problems such as incorrect identification of a plant, lack of standardization in the preparation, contamination, adulteration, etc. In addition, other factors may interfere with the quality and therefore the merit of herbal therapy (Calixto, 2000).

In Brazil, in an attempt to streamline production and make the use of herbal medicines safer, legislation for these products has undergone changes in recent years. The National Health Surveillance Agency (ANVISA) is developing standards for their regulation, based on Ordinance No. 6, 1995, which set deadlines for the pharmaceutical companies to submit data on the efficacy and safety of herbal medicines (Turolla, Nascimento, 2006). This concern of regulators with the standardization of herbal medicines facilitates the evaluation of important aspects such as efficacy and safety of these drugs, including periods of pregnancy and lactation.

Pregnant women and mothers with infants, the population that frequently uses these substances, also believe that they have no adverse reactions or toxic effects. Thus, they rarely seek information from health care professionals about herbal products (Clarke et al., 2007).

In the particular case of pregnant women, the use of any drug or product, either natural or synthetic, must always take into account the risk-benefit ratio (Sanseverino et al., 2001). In this condition, the woman's metabolism and physiological characteristics are altered to focus almost exclusively on promoting the development of the new being carried in her womb, and there are several substances that can harm the developing fetus, especially when used in the first trimester of pregnancy. Even with all these restrictions, studies show that medication use by pregnant women is high. In 2002, Fonseca et al. demonstrated the use of drugs in $94.6 \%$ of pregnant women participating in the study, where $11.2 \%$ used self-medication or layman indication.

Another study by Mengue et al. (2004) assessed the situation in Brazil regarding the pattern of drug use 
in the cities of Porto Alegre, Sao Paulo, Rio de Janeiro, Salvador, Fortaleza and Manaus. The results showed that $83 \%$ of women reported having used some type of drug during pregnancy, with a positive association with level of education, age and the fact of having a companion; these findings are similar to other studies. According to these authors, the results suggested a situation in which drug use is elective, where the greater availability of resources would be a determinant for use. The women of higher socioeconomic status tend to use drugs more frequently compared to mothers with less schooling, young, single and with many children.

An Australian study showed that the use of medicinal plants among pregnant women took second place $(12 \%)$ among the different therapies used by these women (Pinn, Pallet, 2002).

The use of plant substances was also reported by $36 \%$ of pregnant women in Oslo, Norway, with an average of 1.7 products per woman (Nordeng, Havnen, 2005). In the United States, a study of women from rural areas showed that of the $95.8 \%$ of the participants who used at least one type of medication, $92.8 \%$ self-medicated and $45.2 \%$ made use of substances derived from plants during pregnancy (Glover et al., 2003).

The aim of this study was to conduct a literature review on the use of herbs during pregnancy, indicating those that should be avoided during this period because of their abortifacient and/or teratogenic potential, thus debunking the idea that much of the population uses medicinal plants that pose no risk.

With this information, health professionals, especially pharmacists working in community pharmacies may provide better guidance to pregnant women who visit these establishments often seeking natural products to relieve some kind of symptom.

\section{MATERIAL AND METHODS}

We carried out searches in the databases ScienceDirect, Scielo and Google Scholar. The inclusion criteria used were book chapters and/or complete articles (with abstract), available in English, Portuguese or Spanish, published from 1996 to 2011. The search and analysis of the articles were carried out in June to August of 2011 and written work in September to November 2011.

The descriptors used were: Medicinal Plants, Pregnant, Teratogenic Potential, Botanicals, Herbal Drugs, Natural Products, Contraindication, and the scientific names of some of the plants most cited in articles.

The study excluded dissertations, unavailable articles, and papers without abstracts or in languages other than English, Portuguese and Spanish, as well as repeated articles in the databases.

Finally, the texts were analyzed to certify the veracity and consistency of information needed for the research.

\section{RESULTS AND DISCUSSION}

The sample of this review was initially composed of 83 articles. Thirty-four articles were not included in the study because they did not meet the criteria for inclusion, leaving 49 for use in the final analysis of the work. These are listed according to database in Table I.

TABLE I - Total articles used according to database

\begin{tabular}{lccc}
\hline Database & Collection & $\begin{array}{c}\text { Not consistent } \\
\text { with the initial } \\
\text { inclusion } \\
\text { criteria }\end{array}$ & $\begin{array}{c}\text { Quantity end } \\
\text { of articles }\end{array}$ \\
\hline Scielo & 43 & 18 & 25 \\
Sciencedirect & 28 & 10 & 18 \\
Google scholar & 12 & 6 & 6 \\
\hline TOTAL & 83 & 34 & 49 \\
\hline
\end{tabular}

The evaluation of these studies helped achieve a survey of some medicinal plants with potentially teratogenic or abortifacient characteristics. The following are four of these plants reported, which according to Mengue et al. (1997) are the most commonly used as emmenagogue/ abortifacient agents by patients of the Department of Pre-natal Health System. The fifth most often used plant, Egletes viscosa (L.) Less., popularly known by the name of macela-da-terra, was not reported in this paper for lack of sufficient data in the literature on its toxicity and use during pregnancy.

Sena (Senna alexandrina Mill - Fabaceae): this plant species is part of the formulation of numerous products on the domestic market, both in presentations and simple combinations. It is mainly used in the treatment of constipation, and this stimulant laxative is the most commonly used anthranoid laxative worldwide (Robbers, Tyler, 1999).

It is known that constipation problems are very common in pregnant women, affecting about $38 \%$ of patients in this condition (Jewel, Young, 2000). In the case of pregnant women, the use of laxatives containing anthraquinones is potentially dangerous (Clarke et al., 2007), because the ingredients can induce uterine contractions (Conover, 2003), increase blood flow to the uterus and its attachments, increasing the risk of fetal loss, and may pass 
into breast milk and cause unwanted effects such as spasms in the infant (Schulz et al., 2002). For the above mentioned reasons, products containing anthraquinones such as senna, should be avoided during pregnancy (Schulz et al., 2002), especially in the first trimester, the period during which organogenesis occurs and during which malformations can arise from brief exposure.

Arruda (Ruta graveolens L. - Rutaceae) is a medicinal plant commonly used by women for contraception or induced abortion in Brazil and other Latin American countries (Ciganda, Laborde, 2003). It grows as a subshrub with yellow flowers, often cultivated in gardens, where it has strongly scented leaves that are greenish-white and waxy. It originates from countries around the Mediterranean basin, and in folk medicine it is recommended "to induce menstruation," for a soothing feeling, to eliminate lice and to ward off the evil eye (Sanseverino et al., 2001). Several authors mention the use of this species as an abortifacient (Schenkel et al., 2003).

According to Ritter et al. (2002), $R$. graveolens is a plant that contains toxic substances and photosensitizers, which stimulate the motility of the uterus, culminating in abortion, cause lesions and burns on the skin and mucous membranes when exposed to the sun, and this damage is attributed to the presence of furocoumarins. Teratogenicity studies using this experimental plant confirm its toxicity, where it is induces abortion due to the presence of quinoline alkaloids.

In mice, the ingestion of high doses of $R$. graveolens, during pre-implantation is able to induce changes in the blastocyst formation, reducing the number and delaying the development of embryos (Gutierrez-Pajares et al., 2003). Another study, also using mice, showed no significant difference in loss of embryos before implantation between the treated and control groups, but the deaths of fetuses of treated females suggested an embryotoxic effect of $R$. graveolens (De Freitas et al., 2005). Thus, the use of this medicinal plant during pregnancy was not recommended by these authors.

Boldo-do-chile (Peumus boldus Molina - Monimiaceae) is a small tree with leaves opposite, entire, graygreen when dry, with the upper surface rough to the touch and the edges slightly rolled to the bottom side. The leaves have numerous glands, visible to the naked eye, which are responsible for the characteristic aromatic odor. It is originally from Chile, and Brazil is an importer of dried leaves for medicinal use, primarily for the treatment of hepatic disorders in general (Sanseverino et al., 2001).

However, animal studies showed abortive and teratogenic activity for the hydroalcoholic extract of dried leaves and also for the alkaloid boldine, one of its main components, in fetuses from rats previously treated. According to the results observed in a study by Adams et al. (2000), biochemical and histological changes were observed, which suggested moderation and care in using boldo during the first trimester of pregnancy, mainly due to lack of knowledge of the mechanisms of action produced by different substances in the leaves of this plant (Almeida et al., 2000).

Another species, also called boldo or falso boldo (Plectranthus barbatus (Andr.) Benth) was tested in another study by Almeida and Lemonica (2000) with regard to effects on pregnancy in female rats. In folk medicine, this plant is widely used in Brazil as an emmenagogue and for termination of pregnancy. The results demonstrated that the treatment of rats with the highest dose of the extract of boldo before the period of embryo implantation caused a decrease in the number of implantation sites, fetal growth retardation, increased incidence of skeletal abnormalities and reduced number of ossification centers of the fetuses.

Buchinha-do-norte or cabacinha (Luffa operculata L. Cogn. - Cucurbitaceae) is a scandent plant, native of tropical America, cultivated mainly in northern and northeastern Brazil. The fruit is ovoid-oblong, brown when dry, spongy interior, consisting of a woven lattice, sometimes used as "vegetable sponge". The fruit is known in folk medicine for its purgative effect, and recommended for the treatment of some parasitic diseases (Sanseverino et al., 2001).

Records of poisonings with $L$. operculata were performed in the Toxicological Information Center of Santa Catarina (SC-CIT) between 1984 and 1997. These poisonings occurred in ten women aged between 19 and 26 years after ingestion of a variable amount of tea made with dried fruit, which is generally related to attempted abortion (Schenkel et al., 2003).

In another study, the decoction of $L$. operculata administered to female mice during the implantation of embryos caused a reduction in birth rate (Barilli et al., 2005). Besides these four species mentioned by Mengue et al. (1997) as the most commonly used for abortion, there are several other medicinal plants that pose a potential risk to pregnant women.

For example, losna (Artemisia absinthium L.) when ingested in large amounts can cause epileptiform seizures and even abortion, and their use is discouraged by some authors (Robbers, Tyler, 1999). In this case, the toxic action is mainly due to the presence of constituents such as the terpenoid thujone.

Another ingredient that when present in medicinal plants may make them potentially toxic substances is caffeine. Caffeine crosses the placental barrier and decreases 
blood flow to the placenta, where it is singled out as a cause of weight loss in newborns, however, there is not consensus on this activity (Bicalho et al., 2002; Moreira et al., 2001).

Notably, caffeine is considered the most widely consumed stimulant in the world. It is estimated that $75 \%$ of pregnant women in the U.S. consume drinks containing caffeine, including other plants in this group present in yerba mate, black tea, green tea, cola and guarana (Bicalho et al., 2002).

Another commonly used plant that is disparaged is potentially toxic ginger (Zingiber officinale Roscoe - Zingiberaceae). Tsui et al. (2001) showed that the main problem that pregnant women seek to relieve when starting a treatment with products of plant origin is morning sickness, and ginger has been used for centuries in traditional Chinese medicine to relieve morning sickness in pregnant women. There are studies that prove their efficacy in treating nausea and vomiting in pregnancy when compared with placebo, but its mechanism of action is still unclear (Marcus, Snodgrass, 2005; Vutyavanich et al., 2001).

Despite the already established use of ginger, a study showed that ginger caused embryonic loss above normal when administered to rats during pregnancy, but there was also an increase in the weight of the remaining fetuses (Wilkinson, 2000). This plant is taken at a dose of $2 \mathrm{~g} /$ day for the prevention of motion sickness (motion sickness) (WHO, 1999). However, there are many differences in relation to its teratogenic potential.

A study by Weidner and Sigwart (2000) found that an ethanol extract of ginger administered to pregnant rats caused no harm to either mother or developing fetus. Conversely, ginger components are indicated as potential inducers of apoptosis in human cells (Myioshi et al., 2003). The remodeling of the fetal brain and other organs nevertheless involves apoptotic processes, so studies are needed to determine if the constituents of ginger may or may not interfere with these processes (Marcus, Snodgrass, 2005).

\section{CONCLUSION}

This was a small sample of the medicinal plants that can be potentially toxic to pregnant women, refuting the idea that natural products do not pose any health risk. Regarding the safety of these products during pregnancy, information and reliable data are scarce and often contradictory. In this sense, it is critical to conduct studies like the present work, which provides an overview of what we have available in the literature.
Health care professionals, especially pharmacists, need to guide pregnant women in their use of any product of plant origin, without prior consent of their physician, noting the danger of self-medication, and clarify the risks involved in using medicinal plants without proper guidance.

Along this line, it is essential to continue the development of studies on the efficacy, effectiveness and safety of natural products and herbal medicines, to determine their rational use.

\section{REFERENCES}

ALEXANDRE, R.F.; GARCIA, F.N.; SIMÕES, C.M.O. Fitoterapia baseada em evidências Parte I. Medicamentos fitoterápicos elaborados com Ginkgo, hipérico, kava e valeriana. Acta Farm. Bonaer, v.24, n.2, p.300-309, 2005.

ALMEIDA, E.R.; MELO, A.M.; XAVIER, H. Toxicological evaluation of the hydro-alcohol extract of the dry leaves of Peumus boldus and boldine in rats. Phytother. Res., v.14, n.2, p.99-102, 2000.

ALMEIDA, F.G.G.; LEMONICA, I. The toxic effects of Coleus barbatus B. on the different periods of pregnancy in rats. $J$. Ethnopharmacol., v.73, n.1-2, p.53-60, 2000.

AMORIM, E.L.C.; LIMA, C.S.A.; HIGINO, J.S.; SILVA, L.R.S.; ALBUQUERQUE, U.P. Fitoterapia: instrumento para uma melhor qualidade de vida. Infarma, v.3, n.36, p.66-68, 2003.

ASCHWANDEN, C. Herbs for health, but how safe are they? Bull. World Health Org., v.79, n.7, p.691-692, 2001.

BARILLI, S.L.S.; SANTOS, S.T.; MONTANARI, T. Efeito do decocto dos frutos de buchinha-do-norte (Luffa operculata Cogn.) sobre a reprodução feminina e o desenvolvimento embrionário e fetal. In: SALÃO DE INICIAÇÃO CIENTÍFICA (17: 2005: Porto Alegre). Livro de resumos. Porto Alegre: UFRGS, 2005. p.539, resumo 099.

BIAZZI, E. O Maravilhoso poder das plantas. 14ed. Tatuí: Casa Publicadora Brasileira, 2003. 126 p.

BICALHO, G.C.; FILHO, A.A.B. Peso ao nascer e influência do consumo de cafeína. Rev. Saúde Públ., v.36, n.2, p.180$187,2002$.

CALIXTO, J.B. Efficacy, safety, quality control, marketing and regulatory guidelines for herbal medicines (phytotherapeutic agents). Braz. J. Med. Biol. Res., v.33, n.2, p.179-189, 2000. 
CARvalho, A.C.B.; BALBINO, E.E.; MACIEL, A.; PERFEITO, J.P.S. Situação do registro de medicamentos fitoterápicos no Brasil. Rev. Bras. Farmacogn., v.18, n. 2, p.314-319, 2008.

CIGANDA, C.; LABORDE, A. Herbal infusions used for induced abortion. J. Toxicol. Clin. Toxicol., v.41, n.3, p.235239, 2003.

CLARKE, J.H.R.; RATES, S.M.K.; BRIDI, R. Um alerta sobre o uso de produtos de origem vegetal na gravidez. Infarma, v.19, n.1/2, p.41-48, 2007.

CONOVER, E.A. Herbal agents and over-the-counter medications in pregnancy. Best Pract. Res. Clin. En., v.17, n.2, p.237-251, 2003.

CORDEIRO, C.H.G.; CHUNG, M.C.; SACRAMENTO, L.V.S. Interações medicamentosas de fitoterápicos e fármacos: Hypericum perforatum e Piper methysticum. Rev. Bras. Farmacog., v.15, n. 3, p.272-278, 2005.

COSTA, A.F.E.; FROTA, J.G.; LIMA, M.C.; MORAES, M.O. Plantas medicinais utilizadas por pacientes atendidos nos ambulatórios do Hospital Universitário Walter Cantidio da Universidade Federal do Ceará. Pesq. Med. (Fortaleza), v.1, n.2, p.20-25, 1998.

DE FREITAS, T.G.; AUGUSTO, P.; MONTANARI, T. Effect of Ruta graveolens L. on pregnant mice. Contraception, v.71, n.1, p.74-77, 2005.

FONSECA, M.R.C.C.; FONSECA, E.; BERGSTEN-MENDES, G. Prevalência do uso de medicamentos na gravidez: uma abordagem farmacoepidemiológica. Rev. Saúde Públ., v.36, n.2, p.205-212, 2002

FOWLER, M.W. Review plants, medicines and man. J. Sci. Food Agr., v.86, n.12, p.1797-1804, 2006.

GALLO, M.; KOREN, G. Can herbal products be used safely during pregnancy? Focus on Echinacea. Can. Fam. Physician, v.47, p.1727-1728, 2001.

GLOVER, D.D.; AMONKAR, M.; RYBECK, B.F.; TRACY, T.S. Prescription, over-the-counter, and herbal medicine use in a rural, obstetric population. Am. J. Obstet. Gynecol., v.188, n.4, p.1039-1045, 2003.
GUTIÉRREZ-PAJARES, J.; ZÚÑIGA, L.; PINO, J. Ruta graveolens aqueous extract retards mouse preimplantation embryo development. Reprod. Toxicol., v.17, n.6, p.667$672,2003$.

JEWELL, D.J.; YOUNG, G. Interventions for treating constipation in pregnancy. Cochrane Db. Syst. Rev., v.2, Compact Disc 001142, 2000.

LAPA, A.J.; SOUCCAR, C.; LIMA-LANDMAN, M.T.R.; GODINHO, R.O; NOGUEIRA, T.C.M.L. Farmacologia e toxicologia de produtos naturais. In: SIMÕES, C.M.O.; SCHENKEL, E.P.; GOSMANN, G.; MELLO, J.C.P.; MENTZ, L.A.; PETROVICK, P.R. (Org.). Farmacognosia: da planta ao medicamento. 5ed. Porto Alegre: Ed. da UFRGS; Florianópolis: Ed. da UFSC, 2004. p.247-262.

MARCUS, D.M.; SNODGRASS, W.R. Do no Harm: Avoidance of herbal medicine during pregnancy. Obstet. Gynecol, v.105, n.5, p.1119-1122, 2005.

MENGUE, S.S.; SCHENKEL, E.P.; MENTZ, L.A.; SCHMIDT, M.I. Especies vegetales utilizadas por embarazadas con el objeto de provocar la menstuación (Encuesta a siete ciudades de Brasil). Acta Farm. Bonaer, v.16, n.2, p.251258, 1997.

MENGUE, S.S.; SCHENKEL, E.P.; SCHMIDT, M.I.; DUNCAN, B.B. Fatores associados ao uso de medicamentos durante a gestação em seis cidades brasileiras. Cad. de Saúde Públ., v.20, n.6, p.1602-1608, 2004.

MINISTÉRIO DA SAÚDE. Proposta de politica nacional de plantas medicinais e medicamentos fitoterápicos, Brasil, 2001. p.1-40.

MOREIRA, L.M.A.; DIAS, A.L.; RIBEIRO, H.B.S.; FALCÃO, C.L.; FELÍCIO, T.D.; STRINGUETTI, C.; SANTOS, M.D.F. Associação entre o uso de abortificantes e defeitos congênitos. Rev. Bras. Ginecol. Obstet., v.23, n.8, p.517$521,2001$.

MYIOSHI, N.; YOSHIMASA, N.; YASUHIRO, U.; MASAKO, A.; YOSHIO, O.; KOJI, U.; OSAWA, T. Dietary ginger constituents, galanals A and B, are potent apoptosis inducers in Human T lymphoma Jurkat cells. Cancer Lett., v.199, n.2, p.113-119, 2003.

NORDENG, H.; HAVNEN, G.C. Impact of socio-demographic factors, knowledge and attitude on the use of herbal drugs in pregnancy. Acta Obstet. Gyn. Scan., v.84, n.1, p.26-33, 2005. 
OLIVEIRA, F.Q.; GONÇALVES, L.A. Conhecimento sobre plantas medicinais e fitoterápicos e potencial de toxicidade por usuários de Belho Horizonte, Minas Gerais. Rev. Eletr. Farm., v.3, n.2, p.36-41, 2006.

PINN, G.; PALLET, L. Herbal medicine in pregnancy. Compl. Ther. Nurs Midwifery, v.8, n.2, p.77-80, 2002.

RATES, S.M.K. Promoção do uso racional de fitoterápicos: uma abordagem no ensino de farmacognosia. Rev. Bras. Farmacogn., v.11, n.2, p. 57-69, 2001.

REIS, S.R.; MARIOT, A.; STEENBOCK, W. Diversidade e domesticação de plantas medicinais. In: SIMÕES, C.M.O.; SCHENKEL, E.P.; GOSMANN, G.; MELLO, J.C.P.; MENTZ, L.A.; PETROVICK, P.R. (Org). Farmacognosia: da planta ao medicamento. 5ed. Porto Alegre: Ed. da UFRGS; Florianópolis: Ed. da UFSC, 2004. p.45-74.

RITTER, M.R.; SOBIERAJSKI, G.R.; SCHENKEL, E.P.; MENTZ, L.A. Plantas usadas como medicinais no município de Ipê, RS, Brasil. Rev. Bras. Farmacogn., v.12, n.2, p.51-62, 2002.

ROBBERS, J.E.; TYLER, V.E. Tyler's Herbs of choice: the therapeutic use of phytomedicinals. New York: Ed. Haworth Herbal, 1999. 287 p.

SANSEVERINO, M.T.V.; SPRITZER, D.T.; SCHULERFACCINI, L. Manual de Teratogênese. Porto Alegre: Ed. da UFRGS, 2001. p.423-450.

SCHENKEL, E.P.; ZANNIN, M.; MENTZ, L.A.; BORDIGNON, S.A.L.; IRGANG, B. Plantas tóxicas. In: SIMÕES, C.M.O.; SCHEKEL, E.P.; GOSMANN, G.; MELLO, J.C.P.; MENTZ, L.A.; PETROVICK, P.R. Farmacognosia: da planta ao medicamento. 5ed. Porto Alegre: Ed. da UFRGS; Florianópolis: Ed. da UFSC, 2003. p.959-993.

SHULZ, V.; HÄNSEL, R.; TYLER, V.E. Fitoterapia Racional: um guia de fitoterapia para as Ciências da Saúde. Barueri: Ed. Manole, 2002. 386 p.
TSUI, B.; DENNEHY, C.E.; TSOUROUNIS, C. A survey of dietary supplement use during pregnancy at an academic medical center. Ame. J. Obst. Gynecol., v.185, n.2, p.433437, 2001.

TUROLLA, M.S.R; NASCIMENTO, E.S. Informações toxicológicas de alguns fitoterápicos utilizados no Brasil. Rev. Bras. Ciên. Farm., v.42, n.2, p.289-306, 2006.

VUTYAVANICH, T.; KRAISARIN, T.; RUANGSRI, R. Ginger for nausea and vomiting in pregnancy: randomized, doublemasked, placebo-controlled trial. Obstet. Gynecol., v.97, n.4, p.577-582, 2001.

WEIDNER, M.S.; SIGWART, K. Investigation of the teratogenic potential of a Zingiber officinale extract in the rat. Reprod. Toxicol., v.15, n.1, p.75-80, 2000.

WORLD HEALTH ORGANIZATION. World Health Organization monographs on selected medicinal plants. Geneva, 1999. v.1, 289 p.

WILKINSON, J.M. Effect of ginger tea on the fetal development of Sprague-Dawley rats. Reprod. Toxicol., v.14, n.6, p.507$512,2000$.

XU, S.; LEVINE, M. Medical residents' and students' attitudes towards herbal medicines: a pilot study. Can. J. Clin. Pharmacol., v.15, n.1, p.1-4, 2008.

YUNES, R.A.; PEDROSA, R.C.; CECHINEL FILHO, V. Fármacos e fitoterápicos: a necessidade do desenvolvimento da indústria de fitoterápicos e fitofármacos no Brasil. Quím. Nova, v.24, n.1, p.147-152, 2001.

Received for publication on $20^{\text {th }}$ March 2012 Accepted for publication on $18^{\text {th }}$ June 2012 
